\title{
2
}

\section{CRITICAL REFLECTIONS ON CARE}

\author{
Ali Madanipour
}

The coronavirus global pandemic has challenged the perceptions and experiences of urban space and care. The city, which had been celebrated as the future of humanity in the twentyfirst century, became a prison for a while, as state authorities locked people inside their homes, emptying public spaces of almost all human activity. In contrast, the importance of care, particularly health and social care, became paramount. Care workers emerged as the heroes of the hour, and the significance of their work, which hitherto may have been hidden from the view and taken for granted, was now better appreciated. In this context, longstanding questions and tensions of social and ecological care are more pertinent than ever before: What does it mean to care, why is it a cause for concern, whose responsibility is it, and which claims to care can be believed?

To investigate the precarious state of care, this chapter provides some critical reflections on the contexts, concepts, and practices of care. It is structured into three parts. The first part examines the context of the rising attention to care. It locates the concern for care in the larger context of an 'age of carelessness,' with its misplaced sense of confidence, and its intended and unintended consequences, as reflected in and exacerbated by the crises of economic globalization and climate change. The second part investigates the concepts of care, as a relation between need and ability and a response to vulnerability and precarity. It raises questions of who provides and who receives care, the relations of power that are involved, and the threats and gaps that emerge in the commodification of care. The concept of care is examined in relation to social and ecological challenges through the notions of solidarity and reciprocity. The third part provides a critique of some practices of care and how they may be subject to misuse and false claims, as shown in some examples of the different forms of social and ecological care, asking whether some claims to care can stand up to critical scrutiny.

\section{Context of Care: The Age of Carelessness}

The broad historical context for the emergence of a concern for care is the extent to which the urbanized industrial society has transformed the world since the early nineteenth century, triggering what has been named the Anthropocene. Through a combination of ignorance and 
excessive self-confidence, the elite of the industrial society cared little about the social and ecological consequences of their actions. This careless confidence and swaggering attitude were adopted by both capitalist and socialist politics, especially in their reliance on technology, which continues to be treated as the key that can open all locks. It is thought that beyond these locked doors lies a future that, with boundless optimism, can be bent and shaped by the sheer force of will. History is judged harshly, as that which is left behind:The past is associated with a backwardness that needs editing and deleting. The natural world is seen merely in terms of conquest and utility: a beast to fear and to conquer, and/or an endless resource to exploit. The social world is similarly seen through an instrumental framework: Humans are considered as cogs in a machine, driven by utility, desire, and self-interest, all in a narrow concept of the human being. The relationship between humans is considered as a Darwinian competition for supremacy, which leads to deepening inequality at home and colonial domination around the world.

Anxiety about this careless attitude emerged in the late eighteenth and early nineteenth centuries, in parallel with and in response to the growing processes of urbanization and industrialization. The current debates and concerns about the degradation of the natural environment and the growth of social misery and inequality can all be traced back to these early responses, raised by acute observers of society, naturalist romantics, and social revolutionaries (Coupe 2000). The consequences of this carelessness have been stark, both intended and unintended. The impact on the social world has been significant, including alienation, isolation, amnesia, loss of identity, inequality, and social exclusion. The impact on the natural world has also been serious and long lasting, making climate change and the degradation of the natural environment the primary challenge of our time. For the young people who are campaigning for climate emergency, the future is no longer seen with ample optimism but with trembling anxiety.

These negative historical consequences have been exacerbated by a number of recent crises. The ecological crisis and the accelerated pace of climate change is joined by the crises of economic globalization. The structural shifts from manufacturing industries to service economies has led to deindustrialization in many areas, leaving wastelands and unemployed or underemployed masses behind. With the collapse of the welfare state and the marketization and deregulation of public services, the vulnerable masses could no longer receive the care and attention that they deserved. After the global economic crisis of 2008, a number of governments resorted to austerity in public budgets to balance the books and subsequently eliminated the care for the susceptible populations and the natural environment. The age of carelessness was once again unmasked, leading to a rise in vulnerability and precarity, caused by risk-taking that is endemic to capitalism. The COVID-19 pandemic revealed the true extent of vulnerability to crises and the significance of care for all societies.

\section{Concepts of Care: Solidarity and Reciprocity}

According to the dictionary definition, the word care, as a noun, means "The provision of what is necessary for the health, welfare, maintenance, and protection of someone or something;" and "Serious attention or consideration applied to doing something correctly or to avoid damage or risk" (Oxford University Press 2020). As a verb, it means to "Feel concern or interest; attach importance to something;" and to "Look after and provide for the needs of" (ibid.). These definitions show a relationship between something or someone that needs to be 
looked after, someone who is in a position to provide that attention, and all the complexities that such a relationship would involve. This indicates that care is a relationship between need and ability; it is a response to vulnerability and precarity, where precarity indicates an increasing exposure to risk, and vulnerability shows the inability to cope with the circumstances. The existence of need without the presence of the ability to meet that need exposes someone or something to risk and vulnerability, and the provision of that ability to deal with risk and damage lies at the core of the idea of care.

For Martin Heidegger (1962: 237), care is at the core of being human, a primordial condition in our relationship with the world: "Being-in-the-world is essentially care." The question, however, is how this care is articulated and performed. Is it directed toward the pleasures of the self or toward the support of the others (Foucault 1986)? In relation to the natural environment, the question has been whether such care is for the intrinsic values of the environment or for the instrumental use of that environment for us. The tensions of care include the care of the past, which includes heritage, memory, and culture. But it is always contested as to which past and whose memory are being cared for. The care of the present includes the vulnerable social groups but caught up in the questions of who cares and whose needs have priority. The care of the future includes the care of children, future generations, and life on the planet.

In addition to the question of what care is, the question of who provides the care, and its associated power relations, are important as the relationship between carer and cared-for can become unequal. The conditions of vulnerability and precarity indicate that the need and ability are not always co-present within the same agent: One party is needy, and the other is able to provide what is needed. With regard to the natural environment, the ability of ecosystems to heal themselves is limited, and the extent of human intervention has reached such levels that recovery may not even be possible. In the social environment, such abilities may not even exist among the vulnerable populations, especially at the times of disaster. Who provides and who receives the care therefore becomes an unequal relationship of dependency. The carer is endowed with a degree of power over the cared for.

The imbalance of power can also be seen in the vulnerability of the carer. The global COVID-19 pandemic demonstrated the importance, but also the vulnerability, of the carers in society, many of whom have been from ethnic minorities. This is partly rooted in the social division of labor, where the task of care is treated as natural, underpaid, or unpaid, and often low status. Martha Nussbaum (1999: 13) argues that "the voice of care" should not be stereotypically assigned to women. The emotions of love, sympathy, and care are at the heart of ethical life, but these emotions have social origins. While women's propensity to sacrifice their own well-being for that of a larger unit may be morally admirable, it is rooted in their social conditions and should not be taken for granted. Such dispositions, she argues, have often been formed in unjust conditions, reflecting the low priority given to women's well-being, and therefore should be open to critical questioning (ibid.: 10-14).

In the market economy, the relationship of care is commodified, reflecting the inequality that is associated with the unequal distribution of resources. However, poor populations are not able to benefit from commodified care due to their limited financial abilities. In such circumstances, gaps emerge in the provision of care, as either the needy do not have access to the necessary resources or their need is not recognized as a viable commodity. An age-old response has been philanthropy, which is a vertical relationship between the provider and receiver, with limited and often inconsistent provision. A more recent response has been the welfare state, another vertical 
form of provision, which nevertheless is more consistent and egalitarian across populations, decommodifying some forms of care, so as to avoid the limitations of commercial and philanthropic care. With the decline of the welfare state, however, this form of care has been cut back.

To overcome the power imbalance between carer and cared-for, and to see it as a relationship among equals, care can be understood as forms of reciprocity and solidarity, which is a horizontal and more equal relationship between the provider and receiver of care. The modern conception of solidarity originated in France, in the mid-nineteenth century interpretation of the French Revolution's concept of fraternity (Pensky 2008). In some countries, like the United Kingdom (UK), the word is rarely used in public discourse, but the attitude of looking after each other, especially during the period of crisis, is still present. We may identify three forms of solidarity: familial, civil, and social. They correspond to family and friends, groups and associations, and the state, each offering an institutional infrastructure for decommodified support and a potential to combat social exclusion. In a way, solidarity is the other side of the coin from monetary exchange relationships.

Familial solidarity is rooted in the ties of blood and kin and is the oldest and historically the strongest form of support. But family relations have been transformed in modern, urbanized society. For David Hume and Adam Smith in the eighteenth century, the transition in the basis of social relations from kinship and clan to contract and exchange was a positive development (Hill and McCarthy 1999). In this new commercial society, people were able to choose their friends and establish genuine relationships rather than being bound by involuntary ties of kin and clan (ibid.). Hume was particularly interested in 'manners,' patterns of polite good conduct, which would provide a cultural framework for these encounters (Copley and Edgar 1998: xi). Family and friends, however, come under pressure at times of crisis; they may offer certain forms of support, but they are ultimately limited in what they can do.Young people and the elderly, for example, may rely on their family for support, but what if the family itself is in deep trouble and what if it is unable to provide the level of care that is needed? Even when these relationships are strong, a problem remains. Solidarity with friends and family is particular and exclusive. The problem is, as Georg Wilhelm Friedrich Hegel had found out, how to extend the sense of solidarity among friends and relatives to solidarity with strangers (Brunkhorst 2005; Hoelzl 2004).

The city is the place of encounter between strangers. A century ago, the French sociologist Émile Durkheim (1972) distinguished between two types of solidarity, one based on similarity and the other on difference. In traditional societies, the members of society are presumed to be all similar to one another, and social cohesion is secured by holding common beliefs and sentiments. However, this form of solidarity was no longer available in modern society, which was based on individuality and difference. Durkheim argued for a work-based model of solidarity, whereby social cohesion is based on the division of labor and the related occupational associations. He called this model 'organic solidarity', as it shows how the different parts of a body function differently, but all belong to the same organism. In our time, however, economic globalization, technological change, and the transition from manufacturing to services have changed the nature and organization of work and its associated social institutions. Civil solidarity and social cohesion now require us to draw on a variety of more complex forms of social relations. It is in this intersubjective realm, formed around what Michel Foucault (2008: 301) calls "disinterested interests," that civil solidarity is shaped through reciprocal relationships between strangers in often localized networks and associations shaped around a diverse range of issues. 
In German social theory, while Karl Marx located solidarity within the boundaries of class, Jürgen Habermas and Axel Honneth follow the Hegelian concept of recognition in analyzing solidarity. For Habermas, solidarity is "standing in for one another," and for Honneth, it is a symmetrical and reciprocal relationship, a form of mutual recognition (Hoelzl 2004: 46). Again, from our vantage point in the middle of a crisis, we can see that recognition is important, but not enough, as it needs to be supported by access to resources. In December 2014, an All-Party Parliamentary Group in the UK published its report on the shocking extent of hunger in the country, a phenomenon that is not limited to the UK. For example, in 2014, one in seven people in America relied on food banks and 1,000 food banks were in operation in Germany (All-Party Parliamentary Inquiry into Hunger in the United Kingdom 2014: 11). By 2019, the number of food banks had reached 2,000 in the UK, distributing millions of food parcels to distressed populations (Coughlan 2019). However, civil solidarity, too, can be asymmetrical, partial, exclusive, fragmented, and limited in its powers. Many non-profit organizations have relied on state support for their survival, which has become problematic after the global economic crisis and the following politics of austerity.

The mid-twentieth-century welfare states developed national-level frameworks for care and social solidarity; a universal and impersonal basis that goes beyond the personal and interpersonal forms of familial and civil solidarity (Silver 1994). The French Code of Social Security in 1945 (cited in Supiot 2014: 3, own translation) states that "the organization of social security is based on the principle of national solidarity." It was based on the principle of social citizenship, as distinctive from political citizenship, which included all those who contributed to this national pot through their taxes, and in return benefited from it as social and public service users (ibid.). Although the welfare regimes in different European countries varied widely in their strength and coverage (Esping-Andersen 1990), they all showed a growing reliance on the state for social cohesion. However, from the mid-1970s, at the end of what the French call the 'glorious thirty', and with the emergence of neoliberalism, the role of the state in social solidarity has been under attack. Even if it was criticized for having domesticated labor and helping the survival of capital, many of its former critics have mourned the passing of its support.

However, these three forms of solidarity have suffered from serious setbacks in recent years. The social impact of the global economic crises has been most severe on this state-based social solidarity and care. In European policy discourse, there is a shift from unconditional social rights, which were the European Union's focus in earlier iterations of social exclusion, to active inclusion, which is seen as an emphasis on personal responsibility within a neoliberal framework (Madanipour et al. 2015). The international and interregional solidarity that was the basis of the European Union has been tested by the decline of social Europe and the fragmentation of European space into northern and southern, eastern and western parts. At the regional level, the European policies of territorial cohesion are encouraged to adopt a place-based strategy, which demands the regions to stand on their feet, rather than relying on the solidarity and support of others (Barca 2009). With the internationalization and diversity of urban populations, the meaning of society and who can claim to be a member have come under pressure, increasingly from far-right political parties and movements.

The challenges of providing care are bound up with the transformation and decline of the welfare state and the dilemmas of delivering care within neoliberal paradigms. The universal principles of the welfare state, in which all contribute to and all benefit from the common pool, has been further undermined by introducing means-tested and targeted schemes. These 
schemes end up becoming a support for the poor, creating stigmatization and resentment, rather than the dignity of a common platform for solidarity. Rather than a homogenous pool of economic, political, and cultural resources accessible to all its members, a pattern of differentiation and social inequality emerges, whereby this pool has gradually dwindled, and some people are excluded from it in some way.

Civil and familial solidarity is also weakened, but they are expected to fill the gaps left from the decline of social solidarity. Familial solidarity has been weakened by the structural transformation of the household and the growth of individualism. The impact of economic crises on non-profit organizations has been serious, as many relied on state subsidies and support. As this support is withdrawn, many such organizations have disappeared entirely or have been severely reduced in strength and scope. As the three forms of solidarity decline, the provision of care for the vulnerable and socially excluded groups becomes a serious challenge. The three forms of solidarity are interdependent; they all need to be at work to provide care for the vulnerable. The relationship between need and ability can be better addressed when all these forms of ability are combined. As a process of social inclusion, care would require a combination of access to resources and support, to decision-making, and to respect and recognition (Madanipour et al. 2003).

The other side of the coin from social care is ecological care. The scale and impact of ecological degradation has been steadily increasing during the last two centuries, reaching crisis levels today (IPCC 2014). The severity of climate change, as it unfolds before our eyes, has made the urgency of care for the planet felt across the world. It has been argued that the local action by planners and local authorities, or single states, is no longer sufficient (Rees 2018). At one end of the scale, individual action is advocated as a concrete form of such care. Changes in individual behavior and lifestyle are necessary but not sufficient. What is needed, as campaigners are arguing, is global coordination and cooperation to tackle the climate crisis. The formation of intergovernmental panels and conferences is a sign of the need for this cooperation, but the failure of taking appropriate action shows the difficulty of organizing such coordinated efforts. The need for ecological care deepens but is faced with the challenge of mobilizing global action, where the political will and global cooperation are lacking, and the individual and group actions are not sufficient. The sense of solidarity that is required to organize action at all levels is yet to be developed through the three forms of solidarity that we have identified: the familial, civil, and social; mobilizing individuals and households; groups and communities; and societies and states.

Meanwhile, crises may enhance the possibility of solidarity when people bind together in the face of a catastrophe: A major threat mobilizes the popular forces and connects them together through a shared experience. In the UK, the generation who lived through the Second World War remembers this period for its hardship but also for its sense of solidarity, as people felt they shared the same fate in the face of a major struggle. This sense of common experience paved the way for the introduction of a sophisticated welfare state after the war as the institutionalized form of solidarity and care. In the face of the global threats of climate change and the COVID-19 pandemic, the opportunity for mobilizing collective action is opened up so that care for society and environment may be possible.

\section{Practices of Care: Responsibility and Claim}

With regard to the practices of care, two general questions emerge: Who is responsible for delivering care and whether the claims of caring can be trusted to be genuine and sufficient. 
Regarding the first question of who cares, at the broad social and environmental levels, the politics of care become significant. As discussed in the previous section, different levels of action are at work for care: individual, familial, civil, societal, and global. One or more of these levels may be strong in any society, but to be effective, these levels need to be linked through solidarity and reciprocity. However, the politics of care are loaded with controversies about its delivery and the distribution of responsibility among public, private, and civil society actors. A prime example of the tensions about the responsibility for care can be found in healthcare, which is the most common form of care. The responsibility for healthcare has come under pressure in aging societies, where the demands on its physical and institutional infrastructure have increased, where social care is needed alongside healthcare. This pressure has come into sharp focus during the global pandemic. How pressures have been addressed in different countries and regions has also exposed other forms of social vulnerability such as age, ethnicity, and income.

The second question that needs examining is about the claims to care. Many corporations, media, and publicists claim to be engaged in the practices of care. However, the question is: How far can these claims be believed? An example of such a case is Ruskin Square in Croydon, south London. The architecture critic of the Observer newspaper was very impressed by the design of a new square, on a wasteland next to East Croydon Station, a project that invoked "the spirit of John Ruskin [with] remarkable subtlety" (Moore 2012). The architects "wanted to make a place that would be an asset to the area as soon as possible and thereby be richer than "lobby landscapes and pointless trees"' (ibid., original emphasis). Their approach was to draw on the reputation of the nineteenth-century critic, John Ruskin, and his idea of mixing work and play. Their approach was also to work with what was on the site: 76 species of plants, some winding paths, and little hillocks, so that "it grows out of what is already there and creates a setting for what might happen in the future" (Moore 2012). The architects also found that some refugees, who visited the UK Border Agency nearby, played cricket in this area. So they installed two cricket practice nets for these refugees to be able to play there. Their aim was "placing the human activities in a space above its physical form" (ibid.). The impression that the architects and the critics give of the project is care for the environment and people.

If this is the only source of information about this project, the reader ends up with a warm feeling toward this practice of care. However, it should be noted that this was an interim project (Fulcher 2012). On the architects' website about this project, the images are not of the local wildlife and Afghan refugees, but of a landscape of clean surfaces and sharp edges (Muf 2018). From the start, the developers had wanted an interim arrangement while a major new commercial development takes place here. The website of the developers shows their image and expectation of the final outcome, which is a major development project of two million square feet $(186,000$ square meters) of office, residential, and retail space (Ruskin Square 2020). The element of care, which was emphasized for the interim state, has disappeared from the scene, replaced by the commercial considerations of the property development industry and the normal workings of a major metropolis. The element of care appears to have been used for image making and filling a gap while waiting and preparing the ground for what comes afterward. As can be seen from similar projects, the temporary appearance of care may be the other side of the coin from commercial branding or normalizing precarity (Madanipour 2017, 2018).

In the context of the age of carelessness that was mentioned at the start of this chapter, most practices of care are welcome, even if they are temporary and limited. However, there 
are also questions to be asked, which require going beyond images and behind the surfaces: Do the claims that caring practices make stand up to scrutiny? Is care used as a badge, an empty container, a symbolic banner under which contradictions are hidden? Is it reduced to a technical solution to social and environmental problems? Is it co-opted by commercial interests? What sort of places are created when care is claimed? Are they gestures for publicity or genuine practices of care? In the analysis of care, therefore, what is needed is conducting a close and critical examination of the details, contexts, actors, interests, and motivations.

\section{Conclusion}

A growing concern for care has emerged in the context of urbanized capitalism's misplaced self-confidence: With its careless attitude, the consequences of its instrumental actions for society and environment have come to the fore with the crises of globalization and climate change. As a relationship between need and ability, care is a process, a response to vulnerability and precarity, to increasing exposure to risk, and inability to cope with the circumstances. In this context, the question of who cares becomes significant, as the relationship between the carer and the cared-for is not one among equals. There are competing theories and major controversies about the responsibility and target of care: Who should care for what and whom? These questions have become more urgent in the context of the neoliberal states downsizing their welfare commitments on the one hand, and on the other hand refusing to acknowledge the severity of the climate crisis and to cooperate with each other to tackle it. To avoid inequality, inconsistency, and ineffectiveness, social and ecological care need to be based on a process of solidarity and reciprocity, as well as a process of coordination and cooperation at all levels. It is evident that such a major task cannot be solely undertaken by individuals, households, civil society, or the state, or through the market and technology. This remains, however, a normative goal, and many claims to care therefore tend to fall short by being limited in scope, inconsistent in delivery, utilitarian in intention, or co-opted by narrow interests. This is why the processes of care need continuous support, and the claims to care need to be subject to critical scrutiny.

\section{References}

All-Party Parliamentary Inquiry into Hunger in the United Kingdom (2014) Feeding Britain: A Strategy for Zero Hunger in England, Wales, Scotland and Northern Ireland [Online]. London: The Children's Society. Available at https://foodpovertyinquiry.files.wordpress.com/2014/12/food-poverty-fe eding-britain-final.pdf [Accessed 11 March 2020].

Barca, F. (2009) An Agenda for a Reformed Cohesion Policy [Online]. Available at https://ec.europa.eu/ regional_policy/archive/policy/future/barca_en.htm [Accessed 14 January 2020].

Brunkhorst, H. (2005) Solidarity: From Civic Friendship to a Global Legal Community. Cambridge, MA: MIT Press.

Copley, S. and Edgar, A. (1998) David Hume: Selected Essays. Oxford: Oxford University Press.

Coughlan, S. (2019, April 25) Food Bank Supplies Help Record Numbers. BBC News [Online]. Available at https://www.bbc.co.uk/news/education-48037122 [Accessed 14 January 2020].

Coupe, L. (ed.) (2000) The Green Studies Reader: From Romanticism to Ecocriticism. New York: Routledge.

Durkheim, E. (1972) Forms of Social Solidarity. In A. Giddens (ed.) Emile Durkheim: Selected Writings. Cambridge: Cambridge University Press, pp. 123-140.

Esping-Andersen, G. (1990) The Three Worlds of Welfare Capitalism. Cambridge: Polity Press. 
Foucault, M. (1986) The Care of the Self. New York: Pantheon Books.

Foucault, M. (2008) The Birth of Biopolitics. New York: Palgrave Macmillan.

Fulcher, M. (2012, July 26) In Pictures: Muf Unwraps Croydon Cricket Interim Use. Architects Journal [Online]. Available at https://www.architectsjournal.co.uk/home/in-pictures-muf-unwraps-croyd on-cricket-interim-use/8633679.article [Accessed 24 January 2020].

Heidegger, M. (1962) Being and Time. Oxford: Blackwell.

Hill, L. and McCarthy, P. (1999) Hume, Smith and Ferguson: Friendship in Commercial Society. Critical Review of International Social and Political Philosophy 2(4): 33-49.

Hoelzl, M. (2004) Recognizing the Sacrificial Victim: The Problem of Solidarity for Critical Social Theory. Journal for Cultural and Religious Theory 6(1): 45-64.

IPCC (2014) Climate Change 2014: Synthesis Report, Contribution of Working Groups I, II and III to the Fifth Assessment Report of the Intergovernmental Panel on Climate Change [Online]. Core Writing Team, R.K. Pachauri and L.A. Meyer (eds.). Geneva: Intergovernmental Panel on Climate Change. Available at https://archive.ipcc.ch/pdf/assessment-report/ar5/syr/SYR_AR5_FINAL_full_wc over.pdf [Accessed 11 March 2020].

Madanipour, A. (2017) Ephemeral Landscapes and Urban Shrinkage. Landscape Research 42(7): 795-805.

Madanipour, A. (2018) Temporary Use of Space: Urban Processes Between Flexibility, Opportunity and Precarity. Urban Studies 55(5): 1093-1110.

Madanipour, A., Cars, G. and Allen, J. (eds.) (2003) Social Exclusion in European Cities. New York: Routledge.

Madanipour, A., Shucksmith, M. and Talbot, H. (2015) Concepts of Poverty and Social Exclusion in Europe. Local Economy 30(7): 1-21.

Moore, R. (2012, October 28) Ruskin Square, Croydon-Review. Observer [Online]. Available at https://www.theguardian.com/artanddesign/2012/oct/28/muf-ruskin-square-croydon-review [Accessed 24 January 2020].

Muf (2018) Ruskin Square 2018 [Online]. Available at http://muf.co.uk/portfolio/ruskin-square-2018 [Accessed 24 January 2020].

Nussbaum, M. (1999) Sex and Social Justice. Oxford: Oxford University Press.

Oxford University Press (2020) Care. Lexico.com [Online]. Available at https://www.lexico.com/ definition/care [Accessed 25 August 2020].

Pensky, M. (2008) The Ends of Solidarity: Discourse Theory in Ethics and Politics. Albany: State University of New York Press.

Rees, W. (2018) Planning in the Anthropocene. In M. Gunder, A. Madanipour and V. Watson (eds.) The Routledge Handbook of Planning Theory. New York: Routledge, pp. 53-66.

Ruskin Square (2020) Ruskin Square [Online]. Available at http://www.ruskinsquare.com/ [Accessed 24 January 2020].

Silver, H. (1994) Social Exclusion and Social Solidarity: Three Paradigms. International Labour Review 133(5-6): 531-578.

Supiot, A. (2014) Au fondement de la citoyenneté sociale; Ni assurance ni charité, la solidarité. Le Monde Diplomatique 11: 3. 